INSTITUTE OF FORESTRY • BELGRADE

INSTITUT ZA ŠUMARSTVO • BEOGRAD

SUSTAINABLE FORESTRY

COLLECTION 69-70, 2014
ODRŽIVO ŠUMARSTVO

ZBORNIK RADOVA 69-70, 2014

UDK $630 * 416.11+630 * 443.3(497.11)=111$

Original scientific paper

\title{
THE MOST FREQUENT AGENTS OF DAMAGES OF TREES AT THE SAMPLE PLOTS IN SERBIA
}

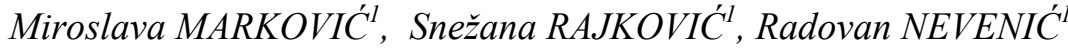

\begin{abstract}
The papers presents the results of the monitoring of damages at 130 sample plots in the grid $16 x 16$ kilometers, which has been continuously conducted in Serbia since 2003. The causes of the damages on the trees can be the consequence of the activity of the series of the adverse agents and owning to it the research of the most significant agents of the damages was made. All damages were classified in the paper by species and types of agents. The occurrence of the mass desiccation of oak forests is to a great extent result of the presence of the agents of powdery mildew. As the example of the use of the data from the database, the spatial arrangement of the plots with the pedunculate oak (which is our most sensitive species) was determined, as well as the infection of them by the powdery mildew. The strongest attack was reported during 2005 and 2006, when 79.3 $\%$ and $77.6 \%$ of the observed trees was infected. The critical month for the occurrence of the intensive infections by the powdery mildew in Serbia is the first half of July, which is important for the creation of the programmes aimed at the protection.
\end{abstract}

Key words: damages, defoliation, chlorosis, powder mildew

\section{НАЈЧЕШЋИ ПРОУЗРОКОВАЧИ ОШТЕЋЕЊА СТАБАЛА НА БИОИНДИКАЦИЈСКИМ ТАЧКАМА У СРБИЈИ}

Извод. У раду су приказани резултати праћења оштећења на 130 биоиндикацијских тачака у мрежи $16 \times 16 \mathrm{~km}$, које се у Србији врши у континуитету од 2003. године. Узроции очтећења на стаблима могу бити последица дејства низа штетних агенаса и зато је вриено истраживање најзначајнијих проузроковача штета. Сва оштећења су у раду класификована по врстама и типовима узрочника.

\footnotetext{
${ }^{1}$ Institute of Forestry, Belgrade, Serbia. E-mail:mira013@gmail.com

Translation: Marija Stojanović
} 
Појава масовног сушења храстових шума је великим делом последица присуства проузроковача пепелнице. Као пример коришћења података из базе, утврђен је просторни распоред тачака са храстом лужнаком (који је наша најосетљивија врста) и ьихова зараженост пепелницом. Најјачи напад је констатован током 2005. и 2006. године, када је заразом захваћено 79,3 и 77,6\% испитиваних стабала. Критичан период за појаву интензивних инфекиија пепелницом у Србији је прва половина јула месеца, ито је значајно за прављење програма заштите.

Кључне речи: оштећења, дефолијација, хлороза, пепелница

\section{INTRODUCTION}

The system of the pieces of information on the health condition of forests is the result of the certain activities within the sustainable forest managent, which is the base for numerous international and national policies. The monitoring of plant diseases and pests is the key element of the ecological policy and without it the standards for the forests and environment cannot be applied (Wulff, 2002). The data processing and reporting are inevitably followed by the uniform methods established by using the international standards (Thomsen et al, 1994; Nevalainen et al, 2010).

The results of monitoring must be available and support the system of biological indicators. The studies and monitoring are conducted by the scientific institutions which prepare the database, evaluations and analyses at the national level (Mues \& Seidling, 2003). The Republic of Serbia has been participated in the ICP forests programme since 2003 via its National Focal Centre (NFC), which in cooperation with the National Expert Group (NEG) makes the analyses of the data and inteprets the results, thereby helping in the scientific management of the Programme and participates in International Expert Panels (IEP) and Working Groups (WG) (Group of authors, 2012). The main aim of the monitoring of crown condition is to obtain the periodical insight into the spatial and temporal variations of crown conditions (Meining et al, 2007), regarding the anthropogenic and natural factors of stress in the European and national systemic networks of the the wideranging monitoring of (Lindgren et al, 2000).

In the aim of the application of the measures of the integral forest protection, the monitoring of the health condition of forests and population sizes of the most important diseases and pests at the sample plots in the Republic of Serbia is continued within the Level 1 and the monitoring of the Level 2 (which, inter alia, encompasses the very detailed studies of the health condition and continuing monitoring of the environmental conditions - temperature and air humidity, which has the direct effect on the occurrence and development of diseases) was introduced, which will provide the very precise diagnostics and forecast of the development of diseases at the most endangered plots in the following period. 


\section{MATERIAL AND METHODS}

Methods of work are described in the first Manual as Visual Assessment of Crown Condition (Eichhorn et al, 2010; Nevalainen and Merilä, 2013) and Submanual on Visual Assessment of Crown Condition on Intensive Monitoring Plots. The Manual has been redesigned recently and enables the harmonized data and more flexible approach to the monitoring of crown condition, of the higher and more transparent quality. All parameters described in the latest version of the Manual have been tested in several countries of Europe and North America, and the values of the parameters have been continuously monitored under the control of the international expert panels. Each necessary harmonization will be recommended at the annual Task meetings Forces) ICP Forests in the following years.

\subsection{Methods of the assessment of trees}

a) The trees are assessed from several directions, if possible (and from two directions, at least).

b) Distance between the observer and the tree should be at least a stem height of observed tree.

c) At the inclined terrain the position of the observer should be above or at the level of the tree.

d) In order to exclude the possibility of sun-blinding and provide as relevant assessment as possible, the observer should avoid to look in the sun during the assessment.

On the marked trees the assessment of the chlorosis (decolorization, loss of colour or the change of the colour of foliage) and defoliation (desiccation of branches) is made on an annual basis in the growing season. The intensity of chlorosis and desiccation is marked by the percentage from 0 to100. In addition, the damages regarding the types and types of the agents are noted in the manuals and marked by the codes: (code 36 marks the enthomologic damages, 38 phytopathological, 40 marks the mechanical damages, etc.). For the biotic agents the Latin name of the agent of damage, phase of the development of the adverse agent, description of the attacked part of plants, age of the attacked needles, etc. are stated along with the code.

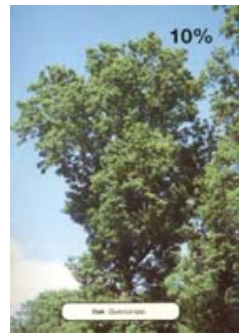

Picture 1

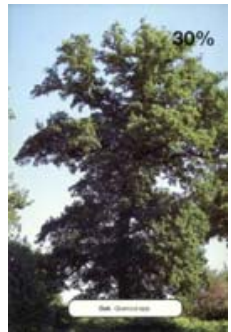

Picture 2

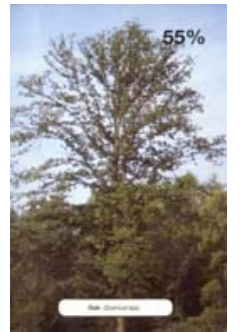

Picture 3

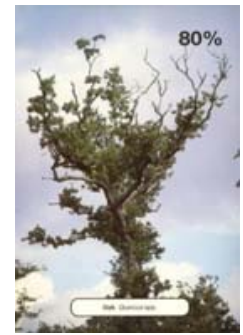

Picture 4

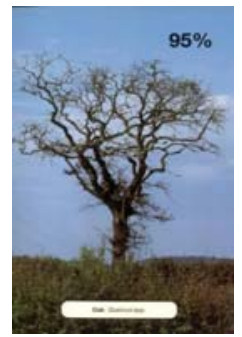

Picture 5

Picture 1-5.The visual determination of the categories of the defoliation of trees 
In the note it is stated on which part of the tree the damage was reported (butt or tree height at which the damage was reported), resin flow or exudates, the presence of litchen, etc. In manuals there are also space for the general remark, which includes all the elements which in anyway can affect the health condition of the stand in which the plot is located (the damages on the young crop at the plot, damages at the stand or in the very vicinity of it, the burnt areas in the vicinity the extreme climate conditions, etc., were reported).

In the pictures from 1 to 5 the visual method of the assessment of the defoliation on the oak, expressed in the percentage $(10,30,55,80$ and 95\%) is depicted. Nevertheless, although the defoliation of crowns is the indicator of the assessment of the condition of trees, the causes of defoliation can be nonspecific and the result of the activity of a range of adverse agents, so it is hardly to identify them with certainty (Ferretti, 1998; Eickenscheidt \& Wellbrock, 2013). Thus, it is necessary to be familiar with the most significant factors which cause damages on trees.

\section{RESULTS AND DISCUSSION}

At 130 sample plots which are being monitored, the most frequent species is the beech, followed by the Turkey oak (these two species account for almost half of all observed trees), Hungarian oak, sessile oak and all other broadleaf species acccount for about two-thirds, and all conifers hardly for one sixth of all the trees. Regarding the conifers, spruce is the most frequent (which accounts for almost a half of all conifers), and fir, Scots and Austrian pines which account for the remaining half of the conifer species.

The most frequent damages at the sample plots in Serbia were classified into two groups: 1) biotic damages caused by the activity of harmful insects, pathogenic and epixylous fungi; 2) abiotic and antropogenic damages caused by the activity of the other adverse agents and man.

\subsection{Agents of the most frequent biotic damages}

Most damages of the trees at the sample plots were caused by the activity of the biotic adverse agents. These damages, based on the place on the tree where they were located, were classified into 4 groups: 1) on leaves and needles 2) on branches 3) on bark 4) on bole and root ( (Marković et al 2005; Marković et al 2011). All damages of the biotic origin were further divided into the damages caused by the activity of harmful insects (entomologic) and damages caused by the activity of fungi (phytopathological) and based on the tree species on which they were reported.

\subsubsection{Agents of the most frequent damages on the leaves and needles.} Most entomologic damages were reported on the oak by the activity of Altica quercetorum Foudras, Thaumatopoea processionea Linnaeus, Lymantria dispar Linnaeus and Tischeria ekebladella (Bjerkander), most phytopathological damages on the beech were caused by Apiognomonia errabunda (Roberge ex Desm.) Höhn., then on the oak by Microsphaera alphitoides Griff. et Maubl. and Mycosphaerella 
maculiformis (Pers.) J. Schröt., and on the pine by Dothistroma pini Hulbary и Lophodermium seditiosum Minter, Staley \& Millar.

3.1.2 Agents of the most frequent damages on the branches. Entomologic damages on the spruce Sacchiphantes viridis Ratzeburg; and phytopathological on the beech Diatrype disciformis (Hoffm.) Fr.

3.1.3 Agents of the most frequent damages on the bark. Entomologic damages on the beech are caused by Cryptococcus fagisuga Lindiger, on the pines and spruce by the bark beetles - Scolytidae sp., and the most frequent phytopathological damages on the beech are caused by Diatrype stigma (Hoffm.) Fr. and fungus Nectria coccinea Desm. which together with the insect C. fagisuga cause the "beech bark disease".

3.1.4 Agents of the most frequent damages on the bole and root. Entomologic damages are mainly caused by the activity of xylophagous insects, mainly by wood wasps - Siricidae sp., and phytopathological ones are caused by the activity of epixylous fungi - Laetiporus sulphureus (Bull.) Murrill, Armillaria melea (Vahl) P. Kumm., Armillaria solidipes Peck and Heterobasidion annosum (Fr.) Bref.

\subsection{The most frequent damages caused by the activity of other factors}

The damages of the trees at the sample plots caused by the activity of the other factors at the sample plots were less frequent, and divided into the anthropogenic and abiotic damages.

3.2.1 Anthropogenic damages caused by the operations during the felling (located on the bole or in the butt - during the extraction and felling).

3.2.2 Abiotic damages caused by the activities of following elements: long-term drought (desiccation of the spruce, pine, oak and beech); intensive cases of insolation (beech bark disease); snow (snow slides and snow throws); wind (wind slides and wind throws); frost (frostbites on the bole and damages of foliage); thunder (thunderbites), etc.

\subsection{Practical usage of database of the sample plots}

The base in which the data from the Sample Plots of Level 1 are collected can be used by segments, which enables the search by the tree species, diseases, pests, periods, etc. The practical usage of the base can be illustrated by the example of the presence of powdery mildew on the pedunculate oak. The agent of powdery mildew Microsphaera alphitoides is one of the most widely spread pathogens which endangered the survival of forests and process of the sustainable management in Serbia and which together with the gypsy moth (Lymantria dispar). and honey fungus (Armillaria mellea) is the main cause of the desiccation of the pedunculate oak forests. 
The plots in the pedunculate oak forests in central Serbia and Vojvodina are currently most endangered when it comes to the occurrence of the agents of powdery mildew and the special attention should be paid to them in order to provide the appropriate protection from this disease. These plots are marked by the numbers: 103, 423, 425, 426, 427 (located in Vojvodina) and plot 86 (located in central Serbia). The sample plots at which the pedunculate oak trees infected by powdery mildew were reported, are located at the following plots: Sample Plot 86 - Forest Estate "Šuma"Leskovac, privately-owned forest, Lapotince; Sample Plot 103 - Forest Estate Sombor, Forest Administration Odžaci, Forest Unit Branjevina, i.e. 12/a; Sample Plot 423 - Forest Estate Sombor, Forest Administration Bački Monoštor, Forest Unit Kolut-Kozara, i.e. 16/d; Sample Plot 426 - Forest Estate S. Mitrovica, Forest Adminisration Klenak, Forest Unit Grabovačko Vitonajevačko island, i.e. 83/g; Sample Plot 427 - Forest Estate S.Mitrovica, Forest Administration Kupinovo, Forest Unit Kupinovske grede, i.e. 47/i.

In the aim of the easier managing and improved transparency, chlorosis and desiccation are grouped and expressed by the indices in the Table 1: chlorosis was presented by the indices from 0 to 3 , and desiccation from the indices from 0 to 4 . (The index 0 refers to the change of colour, i.e. the desiccation up to $10 \%$, index 1: $11-25 \%$, index 2: $26-60 \%$, index 3: above $61 \%$ and index $4100 \%$, i.e. completely desiccated tree). The presentation was made based by the data from the base, for the first seven years of study, i.e. from the beginning of the study (2003), until the first overview in 2009, and the next overview is planned for 2016.

Table 1 Presentation of the percentage of the pedunculate oak trees in the observed categories of health condition

\begin{tabular}{|c|c|c|c|c|c|c|c|c|c|c|}
\hline \multirow{2}{*}{$\begin{array}{c}\text { Year of } \\
\text { Monitoring }\end{array}$} & \multicolumn{4}{|c|}{ Chlorosis (\%) } & \multicolumn{5}{|c|}{ Desiccation (\%) } & \multirow{2}{*}{$\begin{array}{c}\text { Infection by } \\
\text { powdery } \\
\text { mildew } \\
(\%)\end{array}$} \\
\hline & 0 & 1 & 2 & 3 & 0 & 1 & 2 & 3 & 4 & \\
\hline 2003 & 83,3 & 16,7 & 0,0 & 0,0 & 5,6 & 44,4 & 50,0 & 0,0 & 0,0 & $\begin{array}{l}\mathbf{0 , 0} \\
\end{array}$ \\
\hline 2004 & 33,9 & 25,4 & 35,6 & 5,1 & 30,5 & 20,3 & 35,6 & 13,6 & 0,0 & 8,5 \\
\hline 2005 & 50,0 & 34,5 & 13,8 & 1,7 & 29,3 & 31,0 & 27,6 & 12,1 & 0,0 & 79,3 \\
\hline 2006 & 51,7 & 34,5 & 12,1 & 1,7 & 32,8 & 41,4 & 19,0 & 5,2 & 1,7 & 77,6 \\
\hline 2007 & 50,9 & 31,6 & 12,3 & 5,3 & 17,5 & 47,4 & 21,1 & 10,5 & 3,5 & 65,5 \\
\hline 2008 & 63,2 & 26,3 & 1,8 & 8,8 & 8,8 & 49,1 & 24,6 & 8,8 & 8,8 & 61,4 \\
\hline 2009 & 80,4 & 10,7 & 0,0 & 8,9 & 21,4 & 39,3 & 30,4 & 0,0 & 8,9 & 51,8 \\
\hline
\end{tabular}

As it is seen in the Table 1, regarding chlorosis, there was the greatest percentage of the pedunculate oak trees in the category 0 (from $33.9 \%$ in 2004 . to $83.3 \%$ in 2003.), but there was also relatively high percentage of the trees in the categories 1 and 2 and reached as much as 35.6\%, in the index 2 in 2004, and there were many trees in the index 3 - even 8.8 and $8.9 \%$ in 2008. and 2009. Regarding the categories of the pedunculate oak desiccation, the situation is even worse. Most trees were marked by the desiccation index 2, which accounted from $19.0 \%$ in 2006 , to even $50.0 \%$ in 2003 . By the index 4 (which implies the completely desiccated trees) from 8.8 and $8.9 \%$ pedunculate oak trees in 2008 and 2009 was marked. By the index 0 only from $5.6 \%$ in 2003 to $32.8 \%$ in 2006 pedunculate oak trees was marked. The year 2003 generally speaking turned to be very 
unfavourable when it comes to the health condition of the pedunculate oak tree, when chlorosis and desiccation are taking into account as the parameters, and the result of it is the occurrrence of the the less strong infection by the powdery mildew in the following year $(8.6 \%)$. In the following year the culmination phase of the infection, i.e. the strongest attack of the powdery mildew was reported, but over the period of study the infection gradually became less strong, so that in 2009 it reached $51.8 \%$. At the observed pedunculate oak trees the attack of the powdery mildew over the whole period of study is approximately 49.6\%.Practically, it can be stated that pedunculate oak in Serbia is most endangered by the attack of the agents of powdery mildew, and the strongest attack was registered in 2005 and 2006 ( 79.3 and $77.6 \%$ of the observed trees was infected). By the monitoring of the health condition of the pedunculate oak at the sample plots, it was reported that the critical period for the occurrence of the intensive infections by powdery mildew in Serbia is the first half of July, which is important for the creation of the programmes aimed at the protection.

\section{CONCLUSION}

The monitoring of the crown condition is mainly aimed at the provision of the periodical insight into the spatial and temporal variations of the conditions of forests, regarding the anthropogenic and natural factors of stress in the European and national systemic networks of the monitoring of wide range.

In the aim of the application of the measures of the integral forest protection, this paper presents the monitoring of the health condition of forests and population size of the most important diseases and pests at the sample plots in the Republic of Serbia, which provides the very accurate diagnostics and forecast of the development of diseases at the most endangered plots in the following period.

It should be certainly noted that the application of the timely preventive measures, which are aimed at the elimination of the conditions which are favourable to the development of diseases and provide the satisfying resistance and vitality of forest trees. The preventive measures mainly imply the timely regeneration and tending of the forest and forest growing stock, preservation of the biological diversity, professional identification of sites and adequate selection of the appropriate species for the establishment of new forests, selection of the genotypes of forest species resistant to the most significant diseases and pests, use of healthy seeds and seedling material, proper handling of the seedling material, etc.

By the monitoring of the health condition of the pedunculate oak at the sample plots, it was concluded that the critical period for the occurrence of the intensive infections by powdery mildew in Serbia is the first half of July, which is important for the timely creation of the programmes aimed at protection.

The data from the database were used for the presentation of the health condition of the pedunculate oak trees and presence of the powdery mildew, can be similarly used for other tree species as well, other most significant diseases and pests, as well as for other types of the damages of the mechanical and abiotic origin (over the desirable period of time), which opens up great possibilities in the practical application of these studies. 
Acknowledgement: The study was carried out within the Project TR 31070 "The development of technological procedures in forestry with a view to an optimum forest realization", financed by the Ministry of Education, Science and Technological Development of the Republic of Serbia (2010-2015).

\section{REFERENCES}

Eickenscheidt, N., Wellbrock, N. (2013): Consistency of Defoliation Data of the National Ttraining Courses for the Forest Condition Survey in Germany from 1992 to 2012, Environ Monit Assess. 2014; 186(1): 257-275.

Eichhorn, J., Roskams, P., Ferretti, M., Mues, V., Szepesi, A. \& Durrant, D. (2010): Visual Assessment of Crown Condition and Damaging Agents. 49 pp. Manual Part IV. In: Manual on methods and criteria for harmonized sampling, assessment, monitoring and analysis of the effects of air pollution on forests. UNECE ICP Forests Programme Co-ordinating Centre, Hamburg. ISBN: 978-3-926301-03-1.

Ferretti, M. (1998): Potential and Limitation of Visual Indices of Tree Condition. Chemosphere. 36(4-5):1031-1036

Lindgren, M., Salemaa, M. \& Tamminen, P. (2000): Forest Condition in Relation to Environmental Factors. In: Mälkönen, E. (ed.). Forest condition in a changing environment - the Finnish case. Forestry Sciences 65. Kluwer Academic Publishers.p. 142-155.

Marković, M., Tabaković - Tošić, M., Čokeša, V. (2005): The Most Significant Pathogenic and Epixylous Fungi in Tall Beech Forests of Northern Kučaj, Collection of Papers of the Institute of Forestry Belgrade, Volume 52-53: 153-166

Marković, M., Rajković, S., Mladenović, K. (2011): Simultaneous Attacks byLymantria dispar L. and Microsphaera alphitoides Griff. et Maubl. on the Quercus species (Q. cerris, Q. farnetto and Q. petraea), in the Period Since 2004. to 2006. in Some Areas of Serbia, Sustainable Forestry Volume 63-64, pp 123-132, UDK 630, ISSN 1821-1046, COBISS SRID 157148172

Meining, S., Bauer, A., Dammann, I., Gawehn, P., Schröck, H.W. \& Wendland, J. (2007): Waldbäume - Bilderserien zur Einschätzung von Kronenverlichtungen bei Waldbäumen (pp. 128). Kassel, Germany: Verlag M FASTE

Mues, V., \& Seidling, W. (2003). Evaluation of the International Cross-calibration Courses 2001 and 2002., pp. 78. Hamburg, Germany: Institute for World Forestry, Federal Research Centre for Forestry and Forest Products

Nevalainen, S., Lindgren, M., Pouttu, A., Heinonen, J., Hongisto, M. \& Neuvonen, S. (2010): Extensive Tree Health Monitoring Networks are Useful in Revealing the Impacts of Widespread Biotic Damages in Boreal Forests.. Environmental Monitoring and Assessment 168(1): 159-171.

Nevalainen, S. and Merilä, P. (2013): Extensive Monitoring of Forest Condition-Level I in Finland. In: Merilä, P. \& Jortikka, S. (eds.). Forest Condition Monitoring in Finland National report. The Finnish Forest Research Institute. [Online report]. Available at http://urn.fi/URN:NBN:fi:metla-201305087570.

Thomsen, M.G. \& Nellemann, C. (1994): Isolation of Natural Factors Affecting Crown Density and Crown Color in Coniferous Forest: Implications for Monitoring in Forest Decline. Ambio 23(4-5): 251-254. 
Wulff, S. (2002): The Accuracy of Forest Damage Assessments - Experiences from Sweden. Environmental Monitoring and Assessment. 74:295-309. doi: 10.1023/A:1014287228807

***Group of authors (2012): Assessement and Monitoring of the Effects - Impacts of Air Pollution on the Forest Ecosystems in the Republic of Serbia Level I and Level II, NFC for monitoring the condition vitality of the forests in the Republic of Serbia, Belgrade, "Crown Condition Assesement - Intensive Monitoring in 2011"; "Sampling and Analysis of deposition"; "Assesement of the Impact of the Ozone on the Assimilation Organs" (Chapter II, $9 ; 13 ; 14)$, pp 47-53 and 73-79

\title{
THE MOST FREQUENT AGENTS OF DAMAGES OF TREES AT THE SAMPLE PLOTS IN SERBIA
}

\author{
Miroslava MARKOVIĆ, Snežana RAJKOVIĆ,Radovan NEVENIĆ
}

\section{Summary}

The papers presents the results of the monitoring of damages at 130 sample plots in the grid 16x16 kilometers, which has been continuously conducted in Serbia since 2003. The damages were classified in the paper by species and types of agents, but the causes of the damages can be the consequence of the activity of the series of the agents and owning to it the research of the most significant agents of the damages on the trees was made. The occurrence of the mass desiccation of oak forests is to a great extent result of the presence of powdery mildew, which is caused by the pathogenic fungus Microsphaera alphitoides Griff. et Maubl., which particularly occurs on the new, young leaves easily affected by the infections. As the example of the use of the data from the dat base, the spatial arrangement of the plots with the pedunculate oak (which is our most sensitive species) was determined, as well as the infection of them by powdery mildew. The strongest attack was reported during 2005 and 2006, when $79.3 \%$ and 77.6\% of the observed trees was infected. The critical month for the occurrence of the intensive infections by powdery mildew in Serbia is the first half of July, which is important for the creation of the programmes aimed at the protection. The application of the timely preventive measures is very important for the health condition of forests and is aimed at the elimination of the conditions which are favourable to the development of diseases, by providing the satisfying resistance and vitality of forest trees. The preventive measures mainly imply the timely regeneration and tending of the forest and forest growing stock, preservation of the biological diversity, professional identification of sites and adequate selection of the appropriate species for the establishment of new forests, selection of the genotypes of forest species resistant to the most significant diseases and pests, use of healthy seeds and seedling material, proper handling of the seedling material, etc. The data from the database were used for the presentation of the health condition of the pedunculate oak trees and presence of the powdery mildew, can be similarly used for other tree species as well, other most significant diseases and pests, as well as for other types of the damages of the mechanical and abiotic origin (over the desirable period of time), which opens up great possibilities in the practical application of these studies. 


\title{
НАЈЧЕШЋИ ПРОУЗРОКОВАЧИ ОШТЕЋЕЊА СТАБАЛА НА БИОИНДИКАЦИЈСКИМ ТАЧКАМА У СРБИЈИ
}

\author{
Мирослава МАРКОВИЋ, Снежана РАЈКОВИћ, Радован НЕВЕНИћ
}

\section{Резиме}

У раду су приказани резултати праћења оштећења на 130 биоиндикачијских тачака у оквиру мреже $16 x 16 \mathrm{~km}$, које се у Србији врши у континуитету од 2003. године. Оитећења су класификована су по врстама и типовима узрочника, али узрочии итета могу бити последица дејства низа агенаса и зато је вршено истраживање најзначајнијих чинилаца који проузрокују штете на стаблима. Појава масовног сушења храстових шума је великим делом последица присуства пепелнице коју проузрокује патогена гљива Microsphaera alphitoides Griff. et Maubl., која се нарочито јавља на новом, младом лишћу осетљивом на инфекције. Као пример коришћења података из базе, утврђен је просторни распоред тачака са храстом лужнаком и њихова зараженост пепелницом. Констатовано је да је најјачи напад био током 2005. и 2006. године, када је заразом захваћено 79,3 и 77,6\% испитиваних стабала. Критичан период за појаву интензивних инфекиија пепелницом у Србији је прва половина јула месеиа, што је значајно за прављење програма заштите. Спровођење правовремених превентивних мера има велики значај за здравствено стање шума и има за циљ отклањање услова који погодују развоју болести, обезбеђујући задовољавајућу отпорност и виталност шумског дрвећа. Под превентивним мерама подразумевају се, пре свега, благовремена обнова и нега шума и шумских култура, очување биолошке разноврсности, стручна идентификација станишта и правилан избор одговарајућих врста за подизање нових шума, селекција отпорних генотипова шумских врста на најважније болести и штеточине, употреба здравог семена и садног материјала, правилна манипулачија садним материјалом итд. Подаци из базе података који су коришћени за приказ здравственог стања стабала лужњака и присуства пепелнице, могу се на сличан начин користити и за друге врсте дрвећа, остале најважније болести и штеточине, као и друге типове очтећења механичког и абиотичког порекла (у оквиру жељеног временског периода), што отвара широке могућности у практичној примени ових истраживања. 